\title{
Functional properties of cow milk proteins co-precipitate
}

\author{
Rahela Siamand $^{1}$ and Jasim M. S. Al-Saadi ${ }^{2}$ \\ ${ }^{1}$ Food Science Department, College of Agriculture, Salahaddin University, Erbil , Iraq \\ ${ }^{2}$ Dairy Science and Technology Department, College of Food Sciences , AL-Qasim Green \\ University, Iraq
}

\begin{abstract}
The ideal conditions for preparation of cow milk proteins co-precipitate were investigated. The optimum concentration of calcium chloride used to prepare milk proteins co-precipitate was $25 \mathrm{mM}$. This concentration of calcium yielded $96.2 \%$ of milk proteins.

The best $\mathrm{pH}$ values to prepare milk proteins co-precipitate were between (5.5-66.5), while the best heat treatments used were between $85-95^{\circ} \mathrm{C}$ for $20 \mathrm{~min}$.

Solubility of co-precipitate in comparison with sodium caseinate was studied. There were no significant differences between the solubility of cow milk sodium caseinate and cow milk proteins co-precipitate, at $\mathrm{pH}$ values higher than 6 but the solubility of co-precipitate at $\mathrm{pH}$ values lower than 5 was significantly higher than that of cow milk sodium caseinate .

Foaming ability and stability of milk proteins co-precipitate was greater than that of the sodium caseinate. At pH 6 and above the emulsion activity index of cow milk co-precipitate was higher than that of sodium caseinate.
\end{abstract}

\section{Key Words: Cow milk, Proteins co-precipitate , Functional properties .}

\section{Introduction}

Milk contains two major groups of proteins, casein and whey proteins. Caseins are phosphoproteins precipitated from raw milk at $\mathrm{pH} 4.6$ at $20{ }^{\circ} \mathrm{C}$. They comprise approximately $80 \%$ of the total protein content in milk. The principal proteins of this group are classified into $\alpha \mathrm{s}_{1}{ }^{-}, \alpha \mathrm{s}_{2^{-}}, \beta$ - and $\kappa$-caseins (Wong et al. 1996).

During the manufacturing of casein only $80 \%$ of milk proteins are recovered and about $20 \%$ of milk proteins (whey proteins ) are lost .Because of the highly nutritional value and the desired functional properties of whey proteins beside the 
need to increase the quantity of the result proteins, the manufacturing of coprecipitates was developed (Alu'datt et al., 2013).

Milk protein co-precipitates is a technique to prepare the protein precipitate which is resulted from the precipitation of casein and whey proteins using a combination of heat treatments and addition of acid with or without addition calcium salts .They differ from casein and whey proteins in their functional and nutritional properties (Al-Saadi \& Deeth, 2011) .

Heat treatment is essential for the production of co-precipitates because it causes denaturation of whey proteins and their interaction with caseins, particularly the interaction of $\kappa$ - casein and $\beta$-lactoglobulin through disulphide bond formation (Guyomarc'h et al ., 2009). While the function of calcium ions (when added) is to cross-link whey proteins and caseins by the formation of calcium bridges(Al-Saadi \& Deeth, 2011).

Compared with casein, whey proteins are more stable in the presence of ionic calcium salts, but sensitive to heat (Chinprahast et al . 2015). Vattula et al. (1979) recovered $96 \%$ of cow milk proteins by heating skim milk at $85^{\circ} \mathrm{C}$ and adding $0.2 \%$ calcium chloride. Also $0.2 \%$ calcium chloride was sufficient to co-precipitate $97 \%$ of sheep's milk proteins (Al-Saadi \& Deeth, 2011).

Muller et al.(1967) reported that a firm and easy-to-process calcium co-precipitate (with maximum protein recovery) could be manufactured when milk was heated at $90^{\circ} \mathrm{C}$. They also reported that heat treatment required to co-precipitate proteins was much less when calcium was used as the precipitant in comparison to acid precipitation. Three main functions of ionic strength in preparations of milk protein co-precipitates particularly calcium was suggested including electrostatic shielding; ion-specific hydrophobic interaction and cross-linking of anionic molecules through forming bridge between whey proteins and casein proteins ( Deeth \& Lewis, 2015). 
Ju \& Kilara (1998) suggested that the heat -induced aggregation of proteins in the presence of calcium involved the formation of large aggregates, the size of which is dependent on the calcium ion concentration.

\section{Materials and Methods}

\section{Preparation of milk proteins co-precipitate:}

\section{Effect of calcium chloride concentration}

Effect of calcium chloride concentration on preparation of milk proteins coprecipitate was studied following the method described by (Al-Saadi \& Deeth, 2011).

Cow skim milk samples $(100 \mathrm{ml})$ were subjected to pre-heat treatment at $85^{\circ} \mathrm{C}$ for $20 \mathrm{~min}$. in a water bath and cooled to room temperature of $22^{\circ} \mathrm{C}$. Calcium chloride was added to the milk at $22^{\circ} \mathrm{C}$ to give added $\mathrm{Ca}^{2+}$ concentrations of $(0.35,0.7,1.35$, $2.75,3.5,7,10,13.5,17,20,25,30,32.5,35,40) \mathrm{mM}$, and mixed thoroughly. After that samples were heated to $85^{\circ} \mathrm{C}$ for $20 \mathrm{~min}$, then cooled to room temperature, cat to remove whey and filtered through Whatman No. 1 paper. Protein recovery was calculated from the protein concentration of the filtrate using the following equation:

Protein

recovery

$(\%)$ $=$ protein concentration in milk-protein concentration in whey protein concentration in milk

\section{Effect of pH:}

Effect of $\mathrm{pH}$ on preparation of milk proteins co-precipitate was studied following the method described by (Al-Saadi \& Deeth, 2011).The pH of cow skim milk was adjusted to between 5 and 7 using $0.1 \mathrm{~N}$ of Acetic acid and $\mathrm{NaOH}$. skim milk samples were subjected to pre-heat treatment at $85^{\circ} \mathrm{C}$ for $20 \mathrm{~min}$. in a water bath and cooled to $\sim 22^{\circ} \mathrm{C}$. Calcium chloride $(25 \mathrm{mM})$ was added and the milk samples were heated at $85^{\circ} \mathrm{C}$ for $20 \mathrm{~min}$., and then cooled to $22^{\circ} \mathrm{C}$. The samples were 
cutted to remove whey and filtered through Whatman No. 1 paper. Protein concentrations in the filtrate were determined by using this equation:

Protein

recovery $=$

protein concentration in milk-protein concentration in whey $\times 100$

protein concentration in milk

\section{Effect of heating temperature:}

Effect of heating temperature on preparation of milk proteins co-precipitate was studied following the method described by (Al-Saadi \& Deeth, 2011). Cow skim milk samples were heated at temperatures between (60 -95) ${ }^{\circ} \mathrm{C}$ for $20 \mathrm{~min}$, and then cooled to $22^{\circ} \mathrm{C}$. Calcium chloride $(25 \mathrm{mM})$ was added to the samples, then the samples were heated at the same temperature heated before adding calcium chloride $(25 \mathrm{mM})$ for $20 \mathrm{~min}$.The samples were cut to remove whey and filtered through Whatman No. 1 paper, and the protein concentration in the filtrate was determined by using this equation:

recovery

$=$

$\frac{\text { protein concentration in milk-protein concentration in whey }}{\text { protein concentration in milk }} \times 100$

\section{Chemical analysis}

\section{Protein determination:}

Total nitrogen content in sample of (Milk, whey, co-precipitate, calcium-milk coagulum and cheese) was measured by Kjeldahls method (AOAC, 1980) .Protein content in samples was determined by multiplying the percent nitrogen with constant factor 6.38 .

\section{Polyacrylamide Gel Electrophoresis (PAGE) of gel protein:}

Samples were analyzed by the method of Laemmli (1970) with few modifications.

\section{Preparation of sodium caseinate:}


Skim milk was acidified to $\mathrm{pH} 4.6$ with $\mathrm{HCl}(1 \mathrm{M})$ under continuous stirring at $20^{\circ} \mathrm{C}$. After settling for $20 \mathrm{~min}$, the mixture was filtered through Whatman No. 1 paper. The precipitated casein was washed with distilled water, dissolved with the addition of $\mathrm{NaOH}(1 \mathrm{M})$ until the $\mathrm{pH}$ reached 6.8 and precipitated again. The resulting caseinate was resolubilised and freeze-dried (Al-Saadi \& Deeth, 2011).

\section{Functional properties of milk co-precipitate:}

After study the best conditions (milk $\mathrm{pH}$, heat treatment, calcium concentration) for production of milk co-precipitate from cow milk, the resulting milk coprecipitate was freeze-dried to study some of their functional properties such as solubility, foaming and emulsifying activity(Al-Saadi \& Deeth, 2011).

\section{Solubility:}

Stock solutions $(0.1 \%$ in $0.15 \mathrm{M} \mathrm{NaCl}, \mathrm{pH} 7)$ of milk co-precipitate or sodium caseinate were adjusted to the appropriate $\mathrm{pH}(3-10)$ with either $0.1 \mathrm{~N} \mathrm{HCl}$ or $0.1 \mathrm{~N}$ $\mathrm{NaOH}$ and centrifuged at $12000 \mathrm{~g}$ for $15 \mathrm{~min}$ at $25^{\circ} \mathrm{C}$. Protein concentration of the resulting supernatant was determined from the absorbance at $280 \mathrm{~nm}$. Solubility was expressed as the percentage of protein in solution. Means were calculated from a minimum of three runs (Al-Saadi \& Deeth, 2011).

\section{Foaming:}

Foaming properties of milk co-precipitate and sodium caseinate were studied using the gas-sparging method of Waniska \& Kinsella (1979). Fifteen millilitres of samples $(0.1 \%$ in $0.15 \mathrm{M} \mathrm{NaCl}, \mathrm{pH} 7)$ were placed in a column $(1.6 \mathrm{~cm} \times 70 \mathrm{~cm})$. Nitrogen gas was sparged from the bottom of the column for 2 min at a flow rate of $30 \mathrm{~mL} / \mathrm{min}$. Foam height was measured immediately after the gas flow was stopped and at 0.5 minute intervals. Three observations were made of each sample. 


\section{Emulsifying activity:}

Emulsifying activity was determined using the method of Pearce \& Kinsella (1978). Triplicate emulsions of each sample $(0.1 \%$ in $0.15 \mathrm{M} \mathrm{NaCl}$, adjusted to $\mathrm{pH}$ from 3 to 10 with either $0.1 \mathrm{~N} \mathrm{HCl}$ or $0.1 \mathrm{~N} \mathrm{NaOH}$ ) were prepared using $10 \mathrm{~mL}$ of sample and $0.6 \mathrm{~mL}$ of corn oil. The emulsion was prepared by mixing these ingredients for $1 \mathrm{~min}$ at room temperature using blinder .A $0.2-\mathrm{mL}$ aliquot of the emulsion was diluted (1/ 250 final dilution) using $0.1 \%$ sodium dodecyl sulphate (SDS) solution. Turbidity of the emulsion was determined spectrophotometrically at $500 \mathrm{~nm}$.

The emulsion activity index (EAI), which measures the area of interface stabilized per unit weight of protein $\left(\mathrm{m}^{2} / \mathrm{g}\right)$, was calculated using the following equation:

$$
E A I=\frac{(2.303)(2)\left(\mathrm{A}_{500}\right)(\text { dilution factor })}{(\mathrm{c})(1-\text { oil volume })(10000)}
$$

Where $\mathrm{A} 500=$ absorbance at $500 \mathrm{~nm}$, dilution factor is 250 and $\mathrm{c}=\mathrm{g}$ protein $/ \mathrm{mL}$ of aqueous solution before emulsion. Results are the means of 3 replicates.

\section{Results and discussion:}

\section{Effect of calcium chloride on protein recovery in cow milk co-precipitate:}

The effect of the concentration of calcium chloride added to cow skim milk on the protein recovery at $85^{\circ} \mathrm{C}$ for $20 \mathrm{~min}$. is shown in figure (1) that shows that cow milk protein recovery increased with increasing calcium chloride added. At 0.35 $\mathrm{mM}$ addition of calcium chloride, the recovery of milk proteins was $34.1 \%$, and this increased to $93.2 \%$ at $20 \mathrm{mM}$ calcium chloride. The percentage for highest protein recovery was $25 \mathrm{mM}$, which yielded $96.2 \%$ of the milk proteins and this result of recovery was nearly the same found by Vattula et al. (1979) who recover $96 \%$ of milk proteins using the same concentration of calcium.

At higher concentrations of calcium chloride, decrease in protein recovery occurred. The effect of calcium on protein aggregation and recovery is thought to arise from three effects: (i)Electrostatic shielding; (ii) Ion-specific hydrophobic 
interaction; and (iii) Cross-linking of adjacent anionic molecules by forming protein-calcium-protein bridges ( Deeth \& Lewis, 2015).

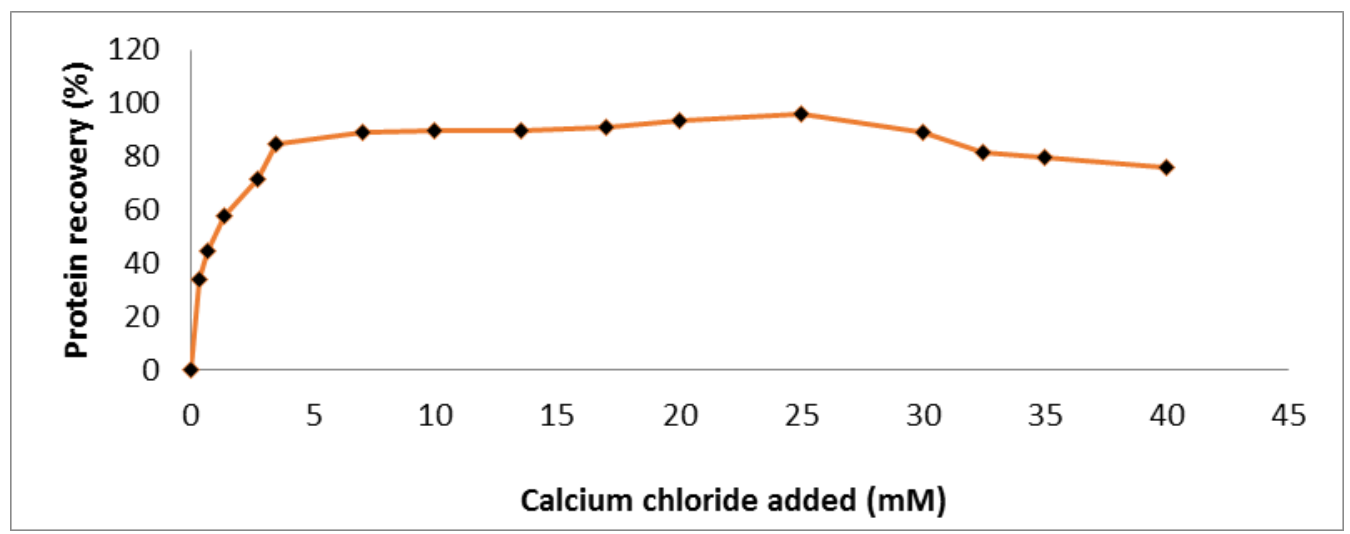

Figure 1: Effect of the quantity of calcium chloride added to cow milk on the protein recovery at $85{ }^{\circ} \mathrm{C}$ for $20 \mathrm{~min}$ at $\mathrm{pH}$ 6.6.

The PAGE gels for milk co-precipitate prepared at different calcium chloride concentrations (Figure 2) showed that at low calcium concentration (0.35 -3.5 mM) the bands of whey protein in co-precipitate were weak but with the increment of calcium concentration used, the amount of $\beta-\mathrm{Lg}$ and $\alpha-\mathrm{La}$ in co-precipitate increased.

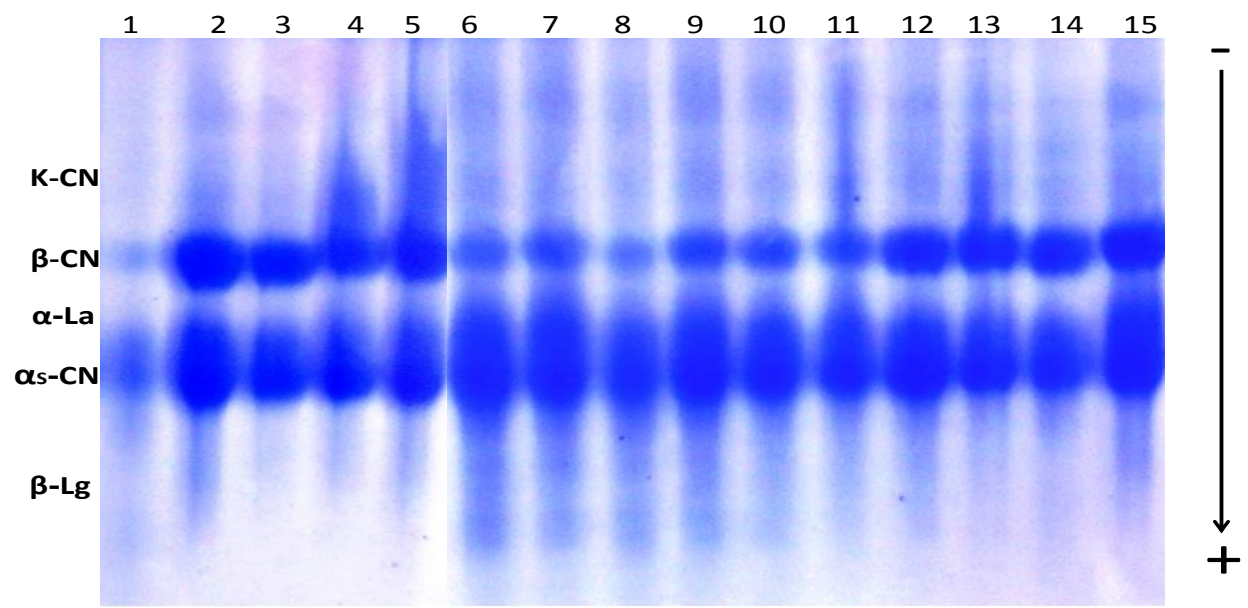

Figure2 : PAGE electrophoretogram of milk co-precipitate samples preparation at different calcium chloride concentrations and heating at $85^{\circ} \mathrm{C}$ for 20 min. Lane $1,2,3,4,5,6,7,8,9,10,11,12,13,14$ and 15 are co-precipitate prepared at calcium chloride concentrations $0.35,0.7,1.35,2.75,3.5,7,10$, $13.5,17,20,25,30,32.5,35$ and $40 \mathrm{mM}$, respectively. 


\section{Effect of pH on protein recovery in cow milk co-precipitate:}

The effect of $\mathrm{pH}$ on protein recovery is shown in Figure (3). At low $\mathrm{pH}$ (5), the recovery of cow milk protein was low $(91.6 \%)$ because the $\mathrm{pH}$ is very close to the isoelectric point of the caseins, which is 4.6 , and this led to the precipitation of casein directly after heating without taking the necessary time to react with whey protein, which resulted in a decrease in protein recovery. Furthermore, lowering the $\mathrm{pH}$ significantly increases the denaturation temperature of $\beta$-Lg (Boye et al.1997). At higher $\mathrm{pH}$ values (5.5-6-6.5), the protein recovery increased because interactions between caseins and whey proteins through disulphide bonds occur (Jang \& Swaisgood, 1990).

These findings are in general agreement with those of Southward \& Aird (1978).At $\mathrm{pH}$ (7) the protein recovery was low (81.3\%). This can be explained by the fact that the level of denatured whey proteins associating with the micelles is depending on the $\mathrm{pH}$ at heating. With increment of $\mathrm{pH}$ the association of whey proteins with casein decreased (Anema \& Li, 2003).

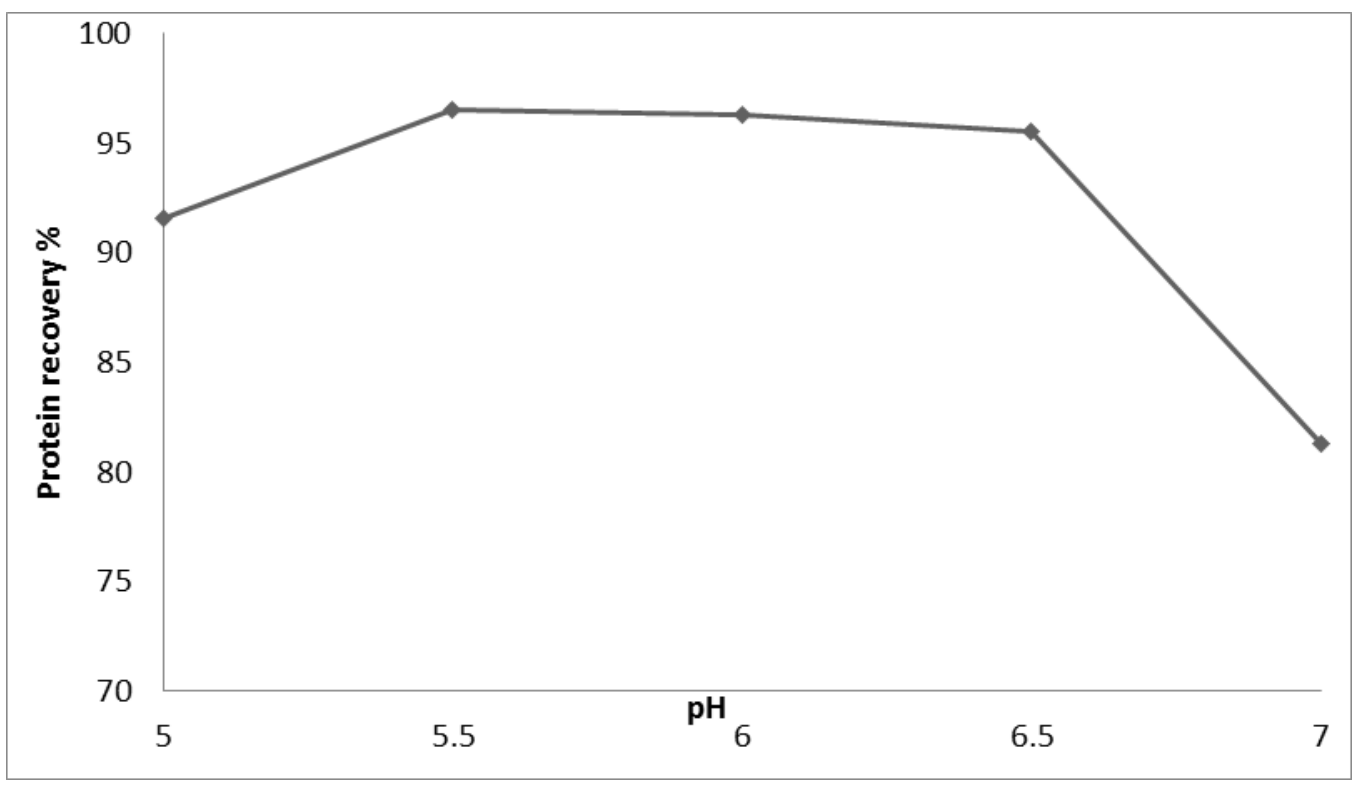

Figure 3: Effect of $\mathrm{pH}$ on protein recovery after adding $25 \mathrm{mM}$ calcium chloride to cow milk and heating at $85^{\circ} \mathrm{C}$ for 20 min. 
The PAGE gels 1, 2 ,3and 4(Figure 4) show that there were no bands in whey samples obtained from preparation milk co-precipitate at $\mathrm{pH} 5,5.5,6,6.5$, while at $\mathrm{pH} 7, \alpha$-La was found in the sample. These results in general agreement with the results obtained in Figure (3).

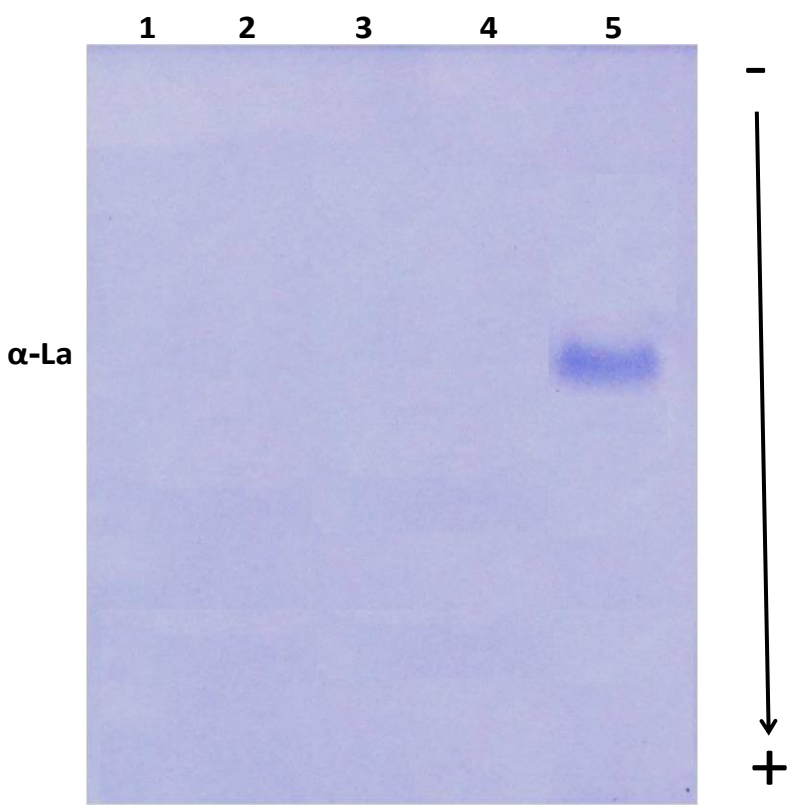

Figure 4: PAGE electrophoretogram of whey samples obtained from preparation milk co-precipitate at different pH values after adding $25 \mathrm{mM}$ calcium chloride and heating at $85^{\circ} \mathrm{C}$ for $20 \mathrm{~min}$. Lane 1, 2, 3, 4 and 5 are coprecipitate whey prepared at $\mathrm{pH} 5,5.5,6,6.5$ and 7 , respectively.

\section{Effect of heating temperature in cow milk co-precipitate:}

The effect of heating temperatures, between 60 and $95^{\circ} \mathrm{C}$, on protein recovery as co-precipitate from cow milk is shown in Figure (5). At the lower temperatures (60$65^{\circ} \mathrm{C}$ ), co-precipitate gels was not formed from cow milk because the amount of calcium binding to casein was less than that required to saturate and cross-link the casein at these temperatures (Ramasubramanian, 2012). 
At $70^{\circ} \mathrm{C}$, casein only was precipitated, heating at this temperature increased the binding of calcium to casein but was not enough to denature whey proteins.

At $75^{\circ} \mathrm{C}$, whey proteins started to precipitate with casein, and at $85-95^{\circ} \mathrm{C}$, the coprecipitate contained the most whey proteins, especially $\alpha-\mathrm{La}$ and $\beta-\mathrm{Lg}$, owing to complex formation between denatured $\beta$-lactoglobulin and K-casein (Reddy \& Kinsella, 1990) and $\alpha$-lactalbumin (Shalabi \& Wheelock, 1976).

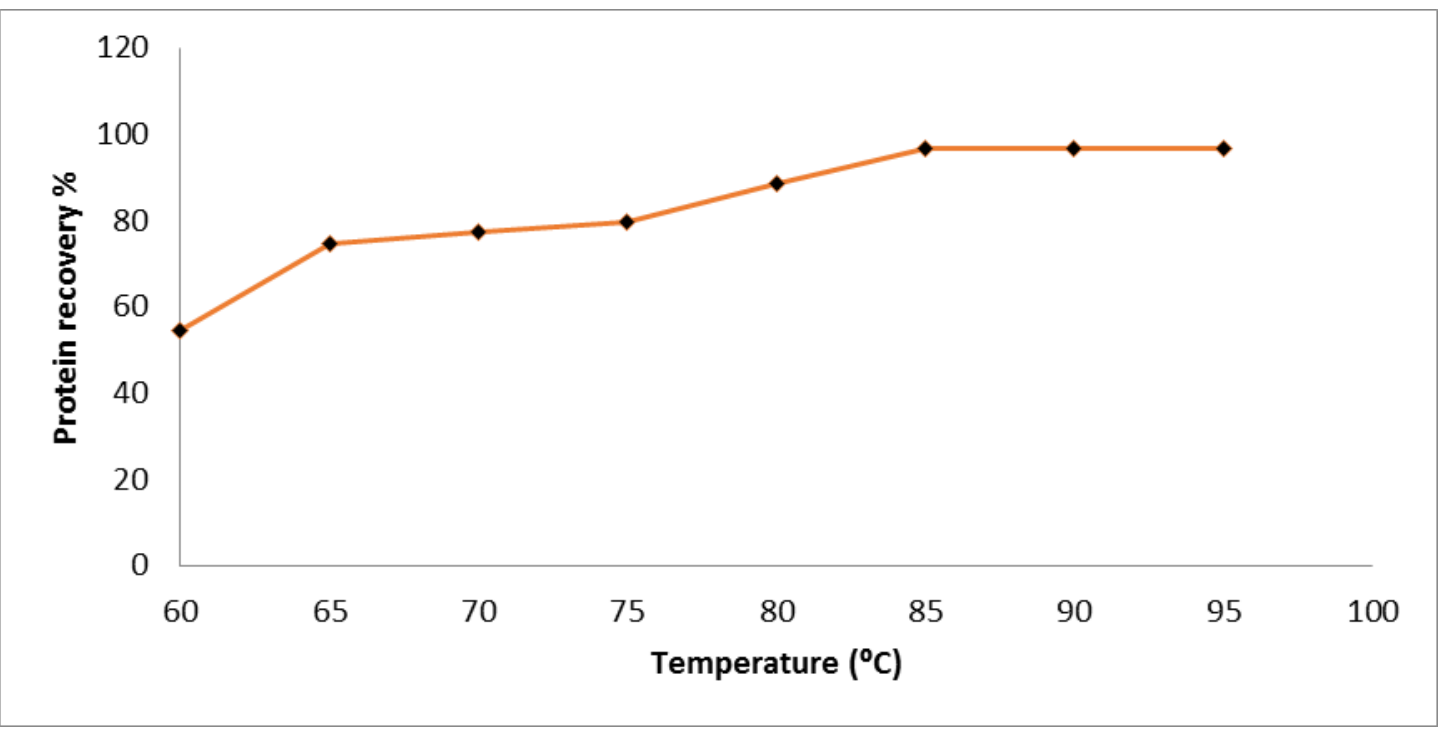

Figure 5:Effect of heating temperature on protein recovery of cow milk after adding $25 \mathrm{mM}$ calcium chloride and heating at different temperature.

The yield of protein in cow milk co-precipitate at $25 \mathrm{mM}$ calcium chloride addition and after heating at $85^{\circ} \mathrm{C}$ for 20 min was $96.6 \%$ and after heating at $95^{\circ} \mathrm{C}$ for 20 $\min$ was $96.8 \%$.

The PAGE of whey obtained from preparation co-precipitate at different temperatures is shown at Figure (6). From this figure we can conclude that at temperatures higher than $80^{\circ} \mathrm{C}$ most of whey proteins $(\alpha-\mathrm{La}$ and $\beta-\mathrm{Lg})$ are bond to casein to form milk proteins co-precipitate. 


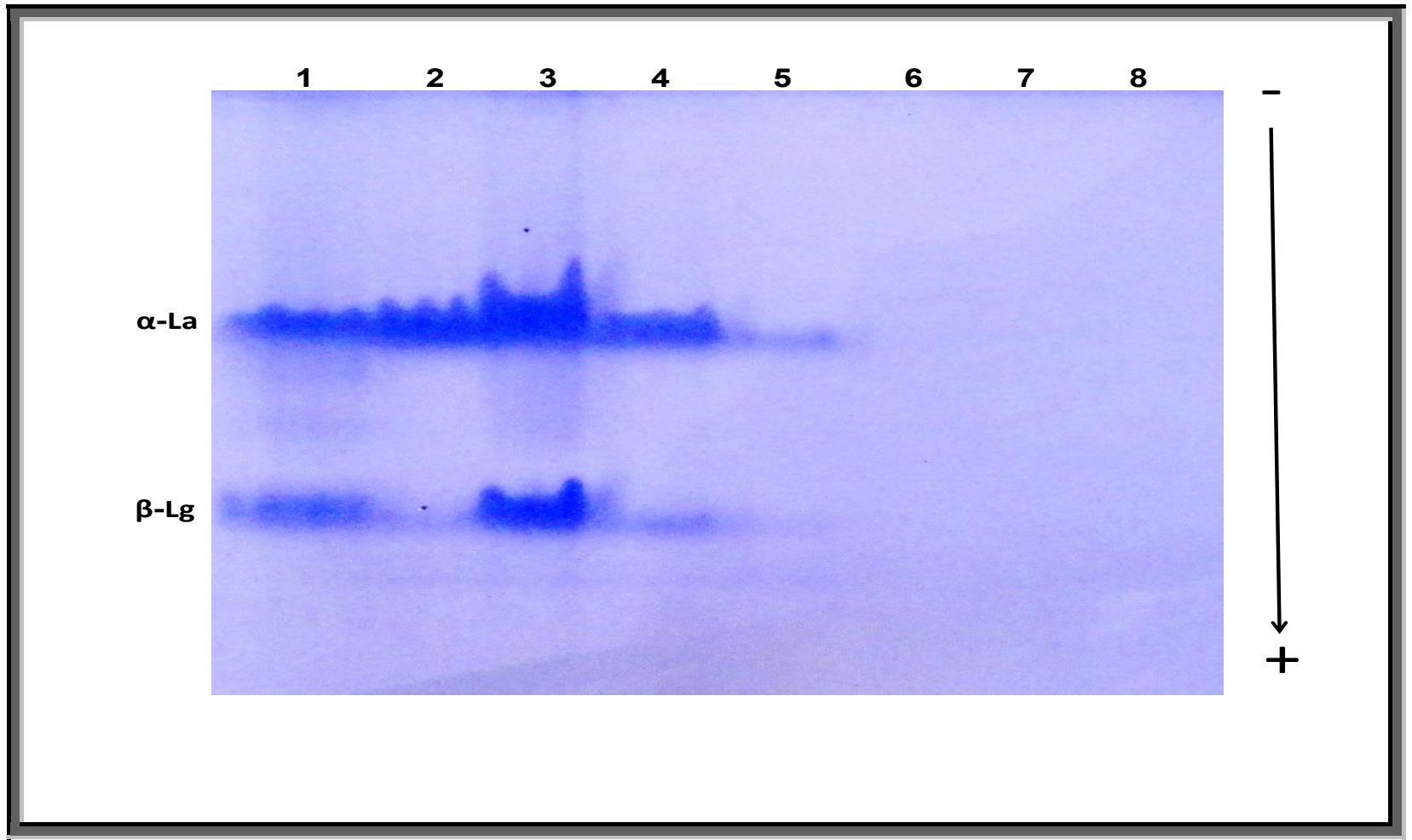

Figure 6 :PAGE electrophoretogram of whey samples obtained from preparation milk co-precipitate prepared after adding $25 \mathrm{mM}$ calcium chloride and heating at different temperatures for $20 \mathrm{~min}$. Lane 1,2, 3, $4,5,6,7$ and 8 are whey samples obtained from co-precipitate prepared at 60, 65,70, 75,80, 85,90 and $95^{\circ} \mathrm{C}$, respectively

Functional properties of cow milk co-precipitate:

Solubility of cow milk co-precipitate:

Solubility characteristics can serve as an index for optimizing the effects of heat on proteins as well as indicating the potential advantages and disadvantages of using the protein in question in particular foods. At $\mathrm{pH}$ values higher than 6 , there were no significant differences between the solubility of cow milk sodium caseinate and cow milk co-precipitate (Figure 7). Sodium caseinate was soluble at $\mathrm{pH}$ values higher than 6 , but its solubility decreased at $\mathrm{pH} 5$ and lower because 
these $\mathrm{pH}$ values are close to the isoelectric point of cow milk casein (Moatsou et al. 2004). The co-precipitate behaved similarly, but its solubility at $\mathrm{pH}$ values lower than 5 was significantly higher than that of casein. This may be related to the presence of $\beta-\mathrm{Lg}$ in the co-precipitate, which distinguishes it from other milk proteins with its high solubility in acidic conditions (Konrad et al. 2000).

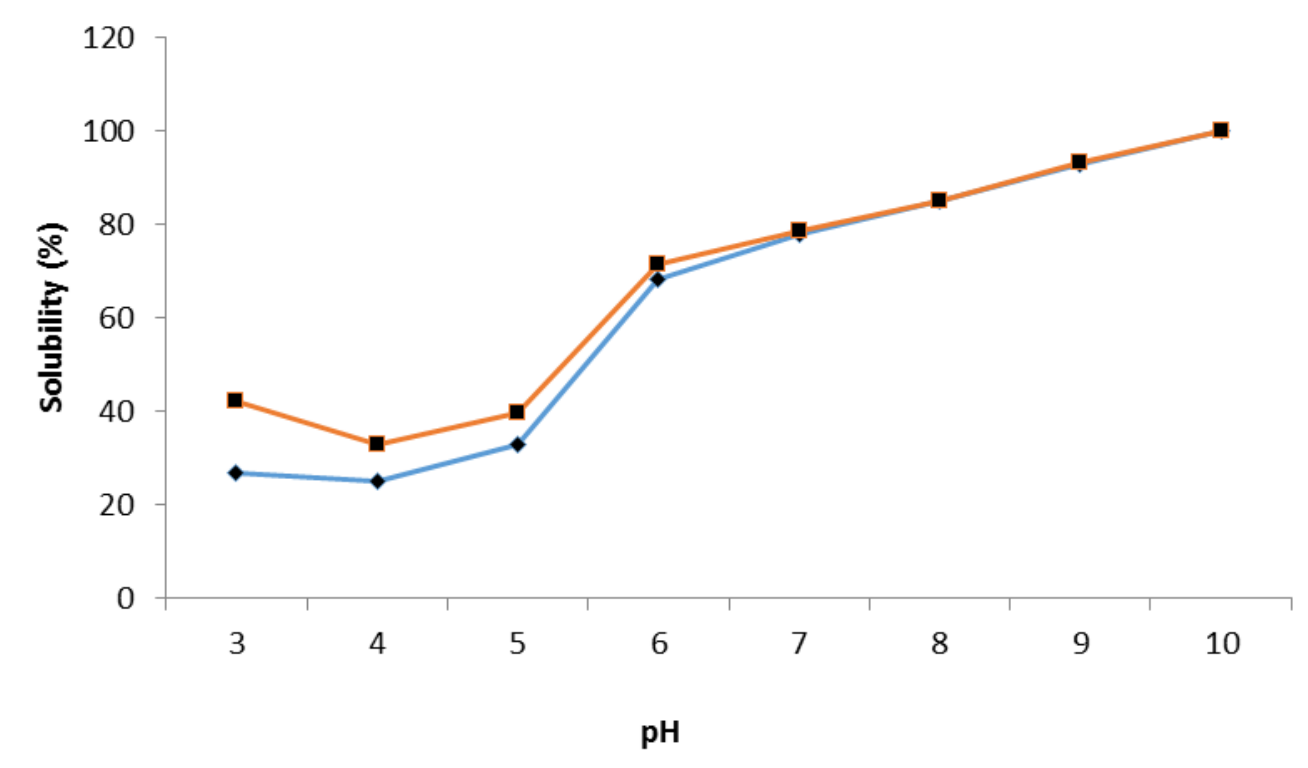

Figure 7: Effect of $\mathrm{pH}$ on the solubility of $0.1 \%$ cow milk co-precipitate $\square$ and $0.1 \%$ cow milk sodium caseinate in $0.15 \mathrm{M} \mathrm{NaCl}$.

\section{Foaming properties of cow milk co-precipitate:}

Formation of a protein foam (liquid-protein-containing phase surrounding a gas bubble phase) is dependent on the protein's surface activity and film-forming properties. Compared with sodium caseinate, co-precipitate solutions produced more foam immediately after sparging (Figure 8), and the stability of the coprecipitate foam was greater than that of the sodium caseinate foam. Co-precipitate foam volume immediately after sparging was $23.5 \mathrm{ml}$ and this volume decreased gradually to zero after $2 \mathrm{~min}$, while sodium caseinate volume immediately after sparging was $5 \mathrm{ml}$ and this volume decreased to zero after $0.5 \mathrm{~min}$. 
This difference may also be related to the heat treatment, which leads to increased surface hydrophobicity (Kato et al. 1983). Foegeding et al. (2006) found that hydrophobicity was a major factor in foam stability.

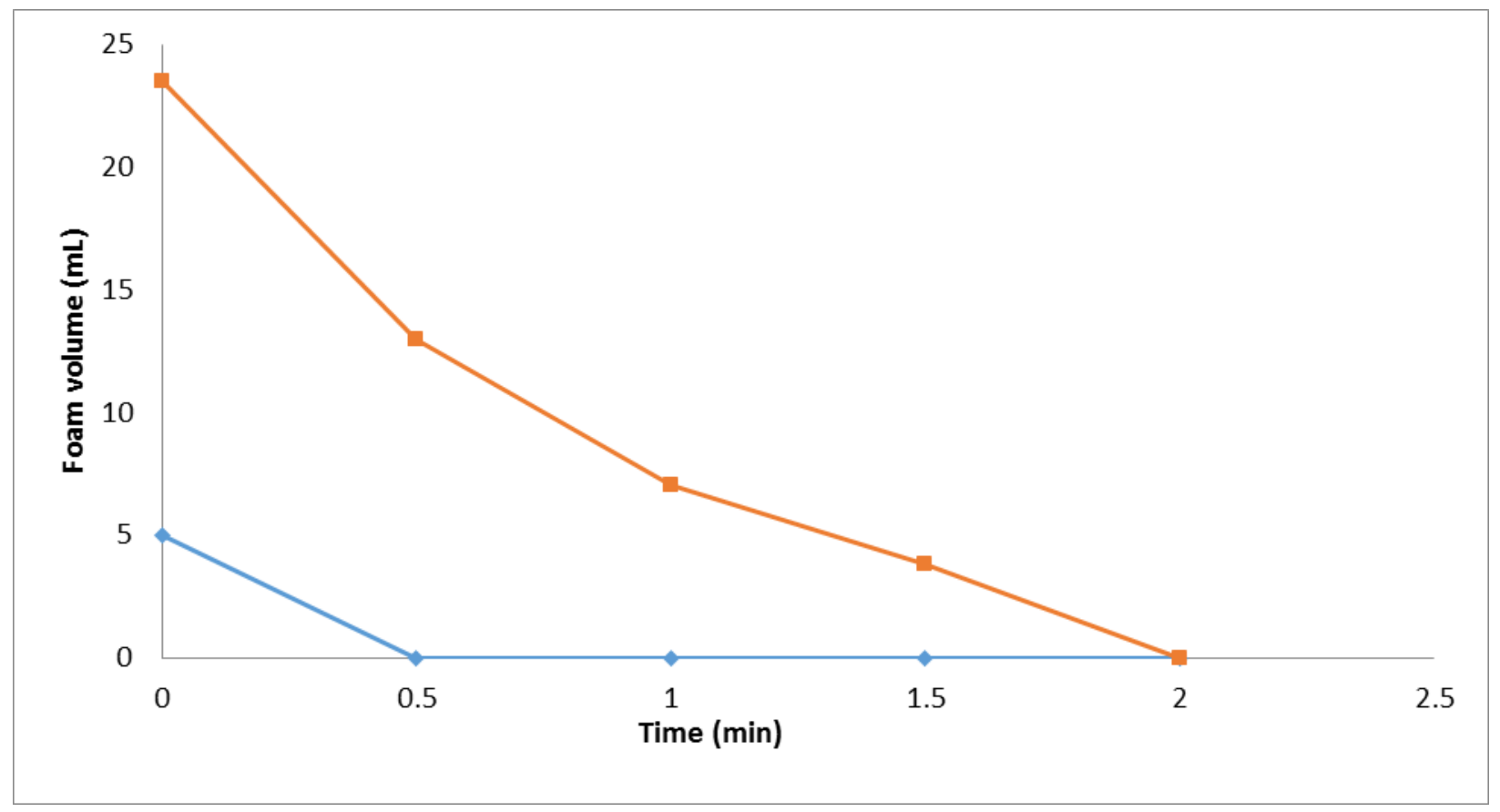

Figure 8: Foam volume $(\mathrm{mL})$ of $0.1 \%$ cow milk co-precipitate $\square$ and $0.1 \%$ cow milk sodium caseinate $\diamond$ in $0.15 \mathrm{M} \mathrm{NaCl}$. Emulsion activity of cow milk co-precipitate:

Emulsification properties depend on the ability of the protein to diffuse to the water oil interface, unfold and orient in such a fashion that the hydrophobic groups associate with the oil, while hydrophilic groups associate with the water phase (Lam \& Nickerson, 2013).

Figure 9, shows the effect of $\mathrm{pH}$ on the emulsion activity index (EAI) of cow milk co-precipitate and cow milk sodium caseinate. The formation of co-precipitate and caseinate emulsions, as evidenced by the turbidity values for freshly prepared emulsions, reflected the amount of soluble protein in the aqueous phase, and because Pearc \&Kinsella, (1978) reported that a minimum of $0.1 \%$ protein was 
essential to obtain reliable data, EAI was calculated only for emulsions made at $\mathrm{pH}$ 6 and higher.

At pH 6 and above (Figure 9) the EAI of cow milk co-precipitate was higher than that of the caseinate. The enhanced emulsifying ability and capacity of the coprecipitate can be attributed to the heat treatment used to produce it which resulted in exposure of previously hidden hydrophobic domains on the protein backbone (Jahaniaval et al.2000).

In addition, Monahan et al. (1996) hypothesized that emulsion droplet aggregation was enhanced by unfolding of both the unadsorbed whey proteins in the continuous phase and the adsorbed proteins at the oil-water interface. In this case, disulphide- mediated polymerization between milk proteins upon heating resulted in increased particle size owing to droplet flocculation.

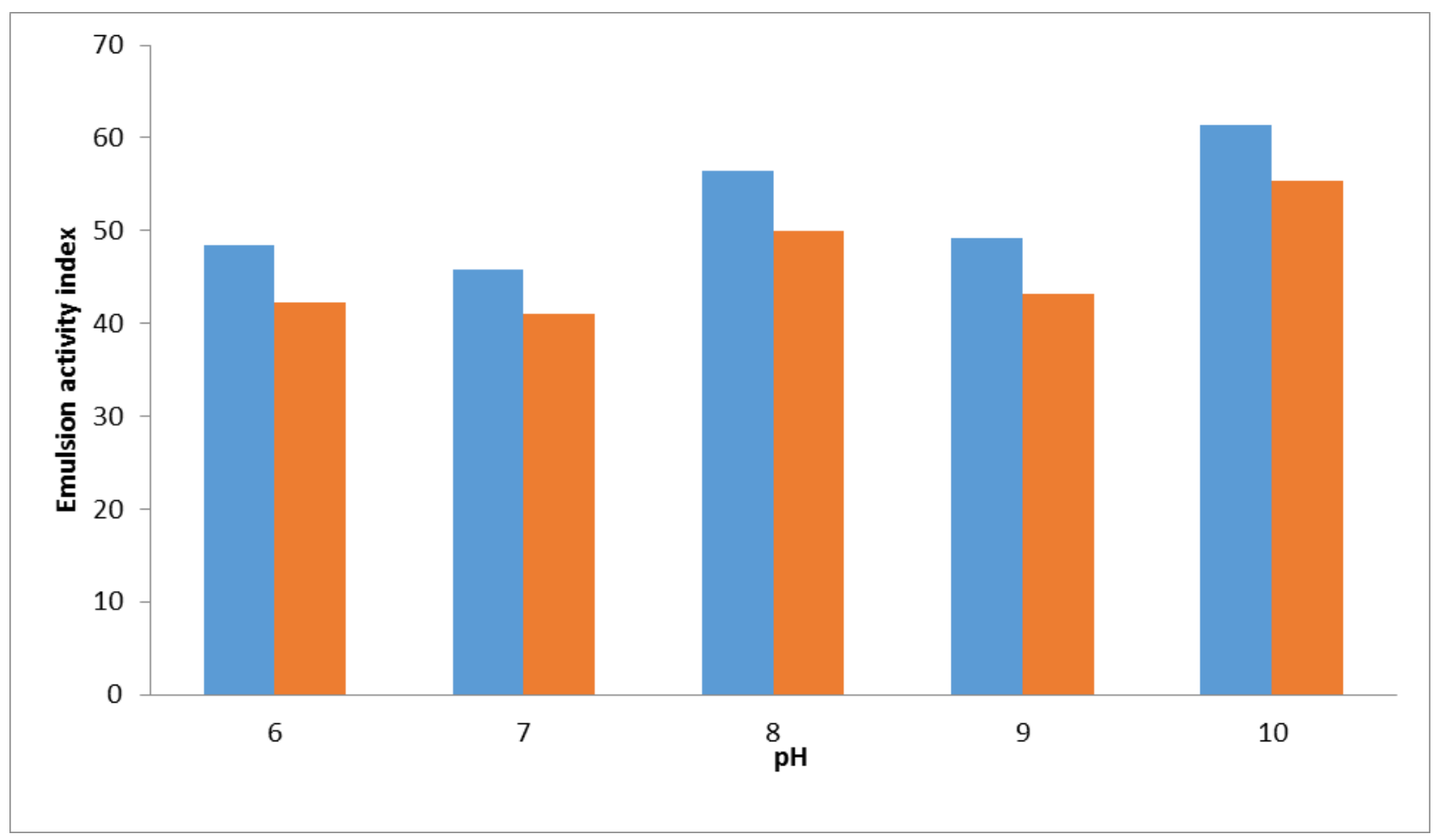

Figure 9: Effect of $\mathrm{pH}$ on the emulsion activity index of $0.1 \%$ cow milk coprecipitate $\square$ and $0.1 \%$ cow milk sodium caseinate $\square$ in $0.15 \mathrm{M} \mathrm{NaCl}$. 


\section{References :}

Association of Official Analytical Chemists, (1980). Official Methods of. Analysis, Washington DC: Association of Official Analytical .Chemists, 13 edition.

AL-Saadi, J. A. S. I. M., \& Deeth, H. C. (2011). Preparation and functional properties of protein coprecipitate from sheep milk. International journal of dairy technology, 64(4), 461-466.

Alu'datt, M. H., Al-Rabadi, G. J., Alli, I., Ereifej, K., Rababah, T., Alhamad, M. N., \& Torley, P. J. (2013). Protein co-precipitates: A review of their preparation and functional properties. Food and Bioproducts Processing, 91(4), 327-335.

Anema, S. G. \& Li. Y. (2003). Effect of pH on the association of denatured whey .proteins with the casein micelles in heated reconstituted skim milk, Journal of. Agricultural and Food Chemistry, 51, 1640-1646.

Boye, J. I. Ma.C.Y. Ismail, A. Harwalkar, V. R. \& Kalab, M. (1997). Molecular and microstructural studies of thermal denaturation and gelation of $\beta$ .lactoglobulins A and B, Journal of Agriculture and Food Chemistry, 45, 1608-. 1618.

Chinprahast, N., Subhimaros, S., \& Pattorn, S. (2015). Heat-acid coagulation of market-returned UHT milk using various coagulants and calcium chloride. International Food Research Journal, 22(3).

Deeth, H. C., \& Lewis, M. J. (2015). Practical consequences of calcium addition to and removal from milk and milk products. International Journal of Dairy Technology, 68(1), 1-10.

Foegeding, E. A., Luck, P. J., \& Davis, J. P. (2006). Factors determining the physical properties of protein foams. Food Hydrocolloids, 20(2), 284-292. 
Guyomarc'h, F., Nono, M., Nicolai, T., \& Durand, D. (2009). Heat-induced aggregation of whey proteins in the presence of $\kappa$-casein or sodium caseinate. Food Hydrocolloids, 23(4), 1103-1110.

Jahaniaval, F., Kakuda, Y., Abraham, V., \& Marcone, M. F. (2000). Soluble protein fractions from $\mathrm{pH}$ and heat treated sodium caseinate: physicochemical and functional properties. Food Research International, 33(8), 637-647.

Jang, H. D. \&Swaisgood, H. E .(1990). Disulfide bond formation between thermally denatured $\beta$-lactoglobulin and k-casein micelles, Journal of Dairy Science, 73,900-904.

Ju, Z. Y., \& Kilara, A. (1998). Aggregation induced by calcium chloride and subsequent thermal gelation of whey protein isolate. Journal of Dairy

Science, 81(4), 925-931.

Kato, A., Osako, Y., Matsudomi, N., \& Kobayashi, K. (1983). Changes in the emulsifying and foaming properties of proteins during heat denaturation. Agricultural and Biological Chemistry, 47(1), 33-37.

Konrad, G., Lieske, B., \& Faber, W. (2000). A large-scale isolation of native $\beta$ lactoglobulin: characterization of physicochemical properties and comparison with other methods. International Dairy Journal, 10(10), 713-721.

Laemmli, U. K. (1970). Cleavage of structural proteins during the assembly of the head of bacteriophage T4. nature, 227(5259), 680-685.

Lam, R. S., \& Nickerson, M. T. (2013). Food proteins: a review on their emulsifying properties using a structure-function approach. Food Chemistry, 141(2), 975-984.

Moatsou, G., Samolada, M., Katsabeki, A., \& Anifantakis, E. (2004). Casein fraction of ovine milk from indigenous Greek breeds. Le Lait, 84(3), 285-296.

Monahan, F. J., McClements, D. J., \& German, J. B. (1996). Disulfide-mediated Polymerization Reactions and Physical Properties of Heated WPI-stabilized Emulsions. Journal of food science, 61(3), 504-509. 
Muller, L. L., Hayes, J. F., \& Snow, N. (1967). Studies on co-precipitates of milk proteins. Australian Journal of Dairy Technology, 22(1), 12.

Pearce, K. N., \& Kinsella, J. E. (1978). Emulsifying properties of proteins: evaluation of a turbidimetric technique. Journal of Agricultural and Food Chemistry, 26(3), 716-723.

Ramasubramanian, L. D'Arcy, B. R. \&Deeth, H.C. (2012). Heat-induced .coagulation of whole milk by high levels of calcium chloride, International .Journal of Dairy Technology, 65 ,183-190.

Reddy, I. M., \& Kinsella, J. E. (1990). Interaction of. beta.-lactoglobulin with. kappa.-casein in micelles as assessed by chymosin hydrolysis: effect of temperature, heating time, beta.-lactoglobulin concentration, and $\mathrm{pH}$. Journal of agricultural and food chemistry, 38(1), 50-58.

Shalabi, S. I., \& Wheelock, J. V. (1976). The role of $\beta$-lactalbumin in the primary phase of chymosin action on heated casein micelles. Journal of Dairy Research, 43(02), 331-335.

Southward, C. R. \&Aird, R. M. (1978). Co-precipitates and their application in .food products I. Observations on the manufacture of coprecipitates, NewZealand Journal of Dairy Science and Technology, 13, 77-96.

Vattula, T., Heikonen, M., Kreula, M., \& Linko, P. (1979). Effects of processing conditions on milk protein coprecipitates. Milchwissenschaft-milk science international, 34(3), 139-142.

Waniska, R. D. \&Kinsella, J. E. (1979). Foaming properties of proteins: evaluationzof a column aeration apparatus using ovalbumin, Journal of .Food Science, 44,1398-1411.

Wong, D. W., Camirand, W. M., Pavlath, A. E., Parris, N., \& Friedman, M. (1996). Structures and functionalities of milk proteins*. Critical Reviews in Food Science \& Nutrition, 36(8), 807-844. 